\title{
Mercury Pollution Linked To Gold Panning In DR Congo: Contamination Of Aquatic Systems And Health Impact On Residents
}

\author{
Jean-Noël Mputu Kanyinda, Nsambu Mukondwa Pascal, and Musibono Dieudonné
}

\begin{abstract}
The interactions between selenium (Se) and mercury ( $\mathrm{Hg}$ ) were assessed on fish, crabs, and molluscs to assess the risks to public health associated with dietary exposure to mercury from their consumption. To this end, mass concentrations of mercury and selenium have been determined in the edible tissues of three species of fish, in crabs and molluses taken from the rivers of the gold zones of Fizi in South Kivu in the Democratic Republic of Congo. We found values greater than $1 \mu \mathrm{g} / \mathrm{g} \mathrm{Hg}$ in all fish samples regardless of the river, but also that the Kimbi River was the most polluted with an average mercury content of about $5 \mu \mathrm{g} / \mathrm{g}$. Crabs and molluses also had $\mathrm{Hg}$ values greater than 1.
\end{abstract}

Index Terms - Aquatic systems, Health impact, mercury, selenium, Se/Hg molar ratio.

\section{INTRODUCTION}

Crabs, fish and shellfish are important sources of protein, essential amino acids, polyunsaturated fatty acids (omega- 3 and omega-6), carbohydrates, glutamic acids, vitamins A, B, $\mathrm{C}$ and $\mathrm{D}$ and minerals (phosphorus, potassium, sodium, calcium, magnesium, zinc, copper, selenium, iron and iodine) in food [1]-[9]. They are involved in the prevention of cardiovascular disease, as well as in the development and functioning of the retina, brain and nervous system [10]. Aquatic organisms such as fish can accumulate amounts of mercury from their direct environment in their tissues [11]. This accumulation occurs either directly by adsorption through the skin and gill membranes during their respiration, or indirectly by ingestion of already contaminated prey [11][13]. Despite their benefits for human health, crabs, fish and molluscs can contain varying amounts of potentially toxic substances, especially heavy metals caused by water pollution [14]-[17].

The presence and dispersion of pollutants in the environment have been a concern for many years. Among the main environmental contaminants, metallic trace elements (ETM) pose serious ecological problems due to their ubiquitous nature, their toxicity and their bioaccumulation power in several animal species, notably aquatic ones (crabs, fish, molluscs, etc.). At low concentrations, mercury and its derivatives have no destructive effect on fish. High exposure causes damage to gill tissue, death occurs by asphyxiation. Aquatic flora can also concentrate the mercury present in its environment. The methylmercury ion and other organomercury compounds are known to be responsible for inhibiting the growth of phytoplankton at concentrations of the order of $0.1 \mu \mathrm{g} / \mathrm{g}$ [18].

Mercury $(\mathrm{Hg})$ is one of the most dangerous contaminants that directly threaten our environment and our health. Methylmercury, formed from inorganic $\mathrm{Hg}$ in aquatic systems is toxic and bioaccumulative, excessive consumption of fish from its waters can be harmful to human health, especially on the brain and nervous system [6], [7], [19].

In the various gold panning sites of the Fizi territory in South Kivu, the waste is directly discharged into the rivers draining the sites, causing unprecedented mercury pollution. The work of Pascal et al. [20] were able to demonstrate the mercury contamination of the various rivers draining the gold panning sites. They also established a link between the various contaminations of rivers, soils and sediments by the activity of gold washers and that the residents had high mercury levels [10], [20]-[22].

Another trace element is selenium (Se), it is an essential micronutrient for mammals, it is naturally produced in the environment. Selenium is present as an active component of the 21 st genetically encoded amino acid, which is necessary for the functioning of enzymes which are important for preventing and reversing oxidative damage, as well as regulating the thyroid hormone and calcium metabolism [23].

Excessive consumption of selenium (Se) can cause toxicity in the body, but in general, it is lower than the recommended daily dose, and its deficiency causes health problems. Selenium is also known to have the potential to prevent disease in humans, so low selenium consumption is essential for life. Selenium enters the aquatic food chain through the particles of selenium consumed by invertebrates and small fish. It is known as an effective agent to detoxify mercury $(\mathrm{Hg})$ and to offer some protection against the toxicity of mercury $(\mathrm{Hg})$ by reducing the accumulation of $\mathrm{Hg}$ in mammals and fish. The presence of selenium in the environment and food is considered to be a bioindicator of the harmful effects of [14], [17], [23], [24].

$\mathrm{The} \mathrm{Hg} / \mathrm{Se}$ molar ratios must be evaluated in order to

Published on June 28, 2020

Jean-Noël Mputu Kanyinda, University of Kinshasa, Democratic Republic of Congo.

(corresponding e-mail: kanyinda2004@gmail.com).

Nsambu Mukondwa Pascal, University of Kinshasa, Democratic Republic of Congo.

Musibono Dieudonné, University of Kinshasa, Democratic Republic of Congo. 
interpret the effects of exposure to $\mathrm{Hg}$ in terms of food safety and evaluation of the risks of consumption of crabs, fish and molluscs for human health. $\mathrm{Se} / \mathrm{Hg}$ molar ratios greater than 1 provide protection against $\mathrm{Hg}$ toxicity and reduce the harmful effects of $\mathrm{Hg}$ [23].

At present, there is no information on the concentration of total mercury $(\mathrm{HgT})$, no data on the level of mercury $(\mathrm{Hg})$ intoxication of these aquatic organisms (crabs, fish and molluscs) in rivers draining gold panning sites. In view of the above, it appears that the crabs, fish, and molluscs from different rivers draining the gold panning sites in the Fizi territory would be exposed to mercury contamination.

\section{MATERIALS AND METHODS}

\section{A. Study zone}

The samples of the fish studied were caught in nine rivers (Kimbi, Mandje, Misisi, Kimuti, Kacumvi, Kuwa, Lubichako, Etó and Makungu) which drain the gold panning sites of the Fizi territory. Fizi is one of the eight territories of the province of South Kivu in the Democratic Republic of the Congo. Geographically, this territory is located between $3{ }^{\circ}$ 30 'and $4^{\circ} 51^{\prime} 32^{\prime}$ south latitude, $27^{\circ} 45^{\prime}$ and $29^{\circ} 14^{\prime} 10^{\prime}$ east longitude. This territory administratively shares borders with the territory of Uvira in the north, the territory of Mwenga and Shabunda in the west, the territory of Kalemie (Tanganyika) in the south and Lake Tanganyika in the east.

\section{B. Materials}

The choice of sampling sites for benthic macroinvertebrates and fish was based on the existence or not of sources of water pollution from the various rivers coming from the gold panning sites. Three fish species (Silurus sp, Oreochromis sp and Haplochromis sp), one species of crab and mollusk were sampled in 2018 from nine rivers in the territory of Fizi (Makungu, Misisi, Kuwa, Kimbi, Lubichako, Etó, Kimuti, Kacumvi and Mandje) in South Kivu in the Democratic Republic of the Congo. The crab, fish and mollusc samples were transported to the laboratory in polyurethane pots containing $10 \%$ formalin in a cooler at $4{ }^{\circ} \mathrm{C}$. For fish specimens, length $(\mathrm{cm})$ and weight $(\mathrm{g})$ were measured in the laboratory. $5 \mathrm{~g}$ meat of crab, fish and mollusc flesh were stored separately in the freezer at $-20^{\circ} \mathrm{C}$ in plastic jars.

\section{Methods}

First, the sample is digested in the presence of hydrochloric acid $(\mathrm{HCl})$ and potassium permanganate $\left(\mathrm{KMnO}_{4}\right)$. This step breaks down organic matter and transforms mercury into $\mathrm{Hg}^{2+}$ form. Hydrochloric acid promotes the rapid decomposition of cinnabar $(\mathrm{HgS})$, resistant to the attack of nitric acid and sulfuric acid. Potassium permanganate provides complete oxidation of organic compounds refractory to acid decomposition. During this stage, manganese is reduced from the $\mathrm{Mn}^{7+}$ form to the $\mathrm{Mn}^{4+}$ form. After digestion, a hydroxylamine chloride solution $\left(\mathrm{NH}_{2} \mathrm{OH} . \mathrm{HCl}\right)$ reduces $\mathrm{MnO}_{2}$ and excess $\mathrm{KMnO}_{4}$ without reducing $\mathrm{Hg}^{2+}$. In the second step, the mercuric ions reduced to elemental mercury, by a solution of stannous chloride $\left(\mathrm{SnCl}_{2}\right)$ are brought in gaseous form into a cell by air bubbling. Mercury in the cell is measured by atomic absorption spectrophotometry SAA at a wavelength of $253.7 \mathrm{~nm}[10]$.

After thawing at room temperature, $0.5 \mathrm{~g}$ of sample (fish, crab and mollusk) are placed in different digestion tubes (100 $\mathrm{mL}$ ) to which are successively added $4 \mathrm{ml}$ of $65 \%$ pure $\mathrm{HNO}_{3}$, $2 \mathrm{ml}$ of pure $\mathrm{H}_{2} \mathrm{SO}_{4} 98 \%$ and $1 \mathrm{~mL}$ of $37 \%$ pure $\mathrm{HCl}$. The tubes are then placed in a water bath at $90 \pm 5{ }^{\circ} \mathrm{C}$ for 70 minutes. After the mineralization has cooled, $5 \mathrm{ml}$ of the $6 \%$ $\mathrm{KMnO}_{4}$ solution are added to it. After 30 minutes of reaction, $5 \mathrm{~mL}$ of $20 \%$ hydroxylamine hydrochloride are added to neutralize the excess of $\mathrm{KMnO}_{4}$. Transfer it to $50 \mathrm{~mL}$ flasks and make up to the mark with distilled water. $5 \mathrm{ml}$ of the filtrates of each solution prepared are introduced into separate vials and $1 \mathrm{ml}$ of the stannous chloride dihydrate solution $\left(\mathrm{SnCl}_{2} .2 \mathrm{H}_{2} \mathrm{O}\right)$ at $10 \%$ is added to each bottle. Atomic absorption spectroscopy type AA 500 equipped with a specific mercury lamp, with a wavelength of $253.7 \mathrm{~nm}$ was used for this purpose for the determination of mercury [10], [22].

\section{Data analysis}

All analyses were triplicated. Mean values and standard deviations were calculated and the results were presented in $\mu \mathrm{g} / \mathrm{g}$ (ppm) wet weight. The molar concentrations ( $\mu \mathrm{mol} / \mathrm{kg}$ ) of $\mathrm{Hg}$ and $\mathrm{Se}$ were calculated by dividing the concentration $(\mu \mathrm{g} / \mathrm{g})$ by the molecular weight $(200.59 \mathrm{~g} / \mathrm{mol}$ for $\mathrm{Hg}$ and 78.9 $\mathrm{g} / \mathrm{mol}$ for $\mathrm{Se}$ ). The molar ratio of Se to $\mathrm{Hg}$ was calculated by the following equation [10], [23]: Molar ratio $(\mathrm{Se} / \mathrm{Hg})=$ molar concentration of $\mathrm{Se}(\mu \mathrm{mol} / \mathrm{kg}) /$ molar concentration of $\mathrm{Hg}$ $(\mu \mathrm{mol} / \mathrm{kg})$.

\section{RESULTS AND DISCUSSION}

The information relating to the fish samples (Silurus $s p$, Oreochromis sp and Haplochromis sp) such as the length, the weight, the place of capture and the number of fish samples used are given in Table I. The mercury contents and in selenium $(\mu \mathrm{g} / \mathrm{g})$ as well as the $\mathrm{Se} / \mathrm{Hg}$ molar ratio are presented in Table II. In Table III we have presented the mercury and selenium concentrations of the crabs and molluscs with the $\mathrm{Se} / \mathrm{Hg}$ molar ratios. We observe that the fishes of the Kimbi and Lubichako rivers presented sizes and weights largely superior to the other rivers.

In relation to the results presented in Table I relating to the mass and size of the different fish (Silurus sp, Oreochromis sp and Haplochromis $s p$ ), we observe some differences by river. These different species of fish (Silurus sp, Oreochromis $s p$ and Haplochromissp) captured in the Kimbi river had relatively high masses compared to the other rivers with respective mean values of $134.7 \pm 2.1 \mathrm{~g}, 58.8 \pm 0.7 \mathrm{~g}$ and $13.7 \pm 0.6 \mathrm{~g}$, followed by the rivers Lubichako $(120.9 \pm 2.3 \mathrm{~g}$; $53.1 \pm 0.6 \mathrm{~g} ; 11.6 \pm 0.5 \mathrm{~g})$, Kuwa $(93.7 \mathrm{~g} \pm 1.3 \mathrm{~g} ; 47.4 \pm 0,7 \mathrm{~g}$; $10.5 \pm 0.6 \mathrm{~g})$, Mandje $(82.7 \pm 1.9 \mathrm{~g} ; 43.3 \pm 0.9 \mathrm{~g} ; 6.4 \pm 0.4 \mathrm{~g})$, Misisi (80.5 $\pm 1.8 \mathrm{~g} ; 36.1 \pm 0.8 \mathrm{~g} ; 8.1 \pm 0.8 \mathrm{~g})$, Makungu $(80.2 \pm 1.6 \mathrm{~g} ; 44.4 \pm 0.6 \mathrm{~g} ; 9.4 \pm 0,5 \mathrm{~g})$, Etó $(61.1 \pm 0.7 \mathrm{~g}$; $35.1 \pm 0.4 \mathrm{~g} ; 7.4 \pm 0.3 \mathrm{~g})$, Kacumvi $(46.5 \pm 0.4 \mathrm{~g} ; 39.2 \pm 0,6 \mathrm{~g}$; $5.9 \pm 0.2 \mathrm{~g})$ and Kimuti $(37.9 \pm 0.4 \mathrm{~g} ; 31.7 \pm 0.5 \mathrm{~g} ; 4.1 \pm 0.1 \mathrm{~g})$. The same observations are made for the sizes of these different species of fish. These variations in masses and sizes would be due to the diversity of the hydrological regimes of the coasts and to the effects of anthropic activities in the lands 
crossed by these rivers on the other hand.

TABLE I: RESULTS RELATING TO THE WEIGHT (G) AND THE SIZE (CM) OF THE FISH SAMPLES

\begin{tabular}{|c|c|c|c|c|c|c|c|}
\hline \multirow{2}{*}{ Rivers } & \multirow{2}{*}{ Sample (n) } & \multicolumn{2}{|c|}{ Silurus sp } & \multicolumn{2}{|c|}{ Oreochromis sp } & \multicolumn{2}{|c|}{ Haplochromis sp } \\
\hline & & Weight (g) & Length (cm) & Weight (g) & Length $(\mathrm{cm})$ & Weight (kg) & Length $(\mathrm{cm})$ \\
\hline Eto ${ }^{\prime}$ & 16 & $61.1 \pm 0.7$ & $5.9 \pm 0.1$ & $35.1 \pm 0.4$ & $4.9 \pm 0.5$ & $7.4 \pm 0.3$ & $3.4 \pm 0.2$ \\
\hline Kacumvi & 22 & $46.5 \pm 0.4$ & $7.6 \pm 0.1$ & $39.2 \pm 0.6$ & $5.9 \pm 0.7$ & $5.9 \pm 0.2$ & $4.4 \pm 0.2$ \\
\hline Kimbi & 17 & $134.7 \pm 2.1$ & $29.8 \pm 1.1$ & $58.8 \pm 0.7$ & $18.5 \pm 1.6$ & $13.7 \pm 0.6$ & $9.7 \pm 0.8$ \\
\hline Kimuti & 17 & $37.9 \pm 0.4$ & $5.2 \pm 0.2$ & $31.7 \pm 0.5$ & $3.8 \pm 0.1$ & $4.1 \pm 0.1$ & $2.9 \pm 0.1$ \\
\hline Kuwa & 18 & $93.7 \pm 1.3$ & $16.7 \pm 1.4$ & $47.4 \pm 0.7$ & $11.9 \pm 0.9$ & $10.5 \pm 0.6$ & $8.6 \pm 0.6$ \\
\hline Lubichako & 23 & $120.9 \pm 2.2$ & $15.7 \pm 1.2$ & $53.1 \pm 0.6$ & $11.2 \pm 0.8$ & $11.6 \pm 0.5$ & $7.7 \pm 0.6$ \\
\hline Makungu & 15 & $80.2 \pm 1.6$ & $13.0 \pm 1.0$ & $44.4 \pm 0.6$ & $9.3 \pm 0.9$ & $9.4 \pm 0.5$ & $7.4 \pm 0.5$ \\
\hline Mandje & 19 & $82.7 \pm 1.9$ & $9.4 \pm 1.1$ & $43.3 \pm 0.9$ & $7.8 \pm 0.7$ & $6.4 \pm 0.4$ & $5.3 \pm 0.6$ \\
\hline Misisi & 21 & $80.5 \pm 1.7$ & $9.5 \pm 1.2$ & $36.1 \pm 0.8$ & $6.2 \pm 0.6$ & $8.1 \pm 0.8$ & $4.7 \pm 0.7$ \\
\hline
\end{tabular}

TABLE II: MASS CONCENTRATION AND MOLAR RATIOS OF MERCURY AND SELENIUM OF DIFFERENT FISH SPECIES

\begin{tabular}{|c|c|c|c|c|c|c|c|c|c|}
\hline & \multicolumn{3}{|c|}{ Silurus sp } & \multicolumn{3}{|c|}{ Oreochromis sp } & \multicolumn{3}{|c|}{ Haplochromis sp } \\
\hline & $\begin{array}{c}\text { Mercury } \\
\text { content }(\mu \mathrm{g} / \mathrm{g})\end{array}$ & $\begin{array}{c}\text { Selenium } \\
\text { content } \\
(\mu \mathrm{g} / \mathrm{g})\end{array}$ & $\begin{array}{l}\text { Molar } \\
\text { ratios } \\
\mathrm{Se} / \mathrm{Hg}\end{array}$ & $\begin{array}{c}\text { Mercury } \\
\text { content } \\
(\mu \mathrm{g} / \mathrm{g})\end{array}$ & $\begin{array}{c}\text { Selenium } \\
\text { content }(\mu \mathrm{g} / \mathrm{g})\end{array}$ & $\begin{array}{l}\text { Molar } \\
\text { ratios } \\
\mathrm{Se} / \mathrm{Hg}\end{array}$ & $\begin{array}{c}\text { Mercury } \\
\text { content } \\
(\mu \mathrm{g} / \mathrm{g})\end{array}$ & $\begin{array}{c}\text { Selenium } \\
\text { content }(\mu \mathrm{g} / \mathrm{g})\end{array}$ & $\begin{array}{c}\text { Molar } \\
\text { ratios } \\
\mathrm{Se} / \mathrm{Hg} \\
\end{array}$ \\
\hline Eto ' & $3.35 \pm 0.13$ & $3.77 \pm 0.35$ & 2.86 & $2.42 \pm 0.18$ & $2.84 \pm 0.65$ & 2.98 & $3.02 \pm 0.13$ & $3.44 \pm 0.06$ & 2.90 \\
\hline Kacumvi & $2.61 \pm 0.02$ & $3.03 \pm 0.16$ & 2.95 & $1.88 \pm 0.06$ & $2.30 \pm 0.07$ & 3.11 & $2.34 \pm 0.08$ & $2.77 \pm 0.05$ & 3.01 \\
\hline Kimbi & $8.28 \pm 1.06$ & $8.69 \pm 0.34$ & 2.67 & $5.95 \pm 0.44$ & $6.31 \pm 0.53$ & 2.70 & $7.46 \pm 0.32$ & $7.87 \pm 0.43$ & 2.68 \\
\hline Kimuti & $1.57 \pm 0.03$ & $1.99 \pm 0.04$ & 3.22 & $1.14 \pm 0.07$ & $1.56 \pm 0.02$ & 3.48 & $1.42 \pm 0.01$ & $1.83 \pm 0.03$ & 3.28 \\
\hline Kuwa & $2.16 \pm 0.12$ & $2.58 \pm 0.07$ & 3.04 & $1.55 \pm 0.07$ & $1.96 \pm 0.08$ & 3.21 & $1.93 \pm 0.03$ & $2.35 \pm 0.03$ & 3.10 \\
\hline Lubichako & $3.04 \pm 0.03$ & $3.46 \pm 0.37$ & 2.89 & $2.19 \pm 0.33$ & $2.61 \pm 0.65$ & 3.03 & $2.74 \pm 0.04$ & $3.15 \pm 0.06$ & 2.92 \\
\hline Makungu & $3.63 \pm 0.25$ & $4.05 \pm 0.42$ & 2.84 & $2.62 \pm 0.20$ & $3.05 \pm 0.66$ & 2.96 & $3.29 \pm 0.07$ & $3.68 \pm 0.09$ & 2.84 \\
\hline Mandje & $1.89 \pm 0.02$ & $2.31 \pm 0.06$ & 3.11 & $1.36 \pm 0.08$ & $1.78 \pm 0.08$ & 3.33 & $1.69 \pm 0.02$ & $2.11 \pm 0.03$ & 3.17 \\
\hline Misisi & $3.81 \pm 0.27$ & $4.22 \pm 0.13$ & 2.82 & $2.75 \pm 0.17$ & $3.17 \pm 0.66$ & 2.93 & $3.43 \pm 0.07$ & $3.84 \pm 0.09$ & 2.85 \\
\hline
\end{tabular}

The average value of the total mercury content in fish Silurus sp caught in rivers (Makungu, Misisi, Kuwa, Kimbi, Lubichako, Etó, Kimuti, Kacumvi and Mandje) from gold panning sites in Fizi is greater than 1 with a maximum of approximately $8.3 \mu \mathrm{g} / \mathrm{g}$ of fish. As shown in Table II, fish in the Kimbi River have the highest concentration of mercury of all the other rivers. With an average of $8.28 \mu \mathrm{g} / \mathrm{g}$ followed respectively by fish from the rivers Misisi $3.81 \mu \mathrm{g} / \mathrm{g}$, Makungu $3.65 \mu \mathrm{g} / \mathrm{g}$, Eto' $3.05 \mu \mathrm{g} / \mathrm{g}$, Lubichako $3.04 \mu \mathrm{g} / \mathrm{g}$, Kacumvi $2.61 \mu \mathrm{g} / \mathrm{g}$, Kuwa $2.16 \mu \mathrm{g} / \mathrm{g}$, Mandje $1.89 \mu \mathrm{g} / \mathrm{g}$ and Kimuti with a concentration of $1.57 \mu \mathrm{g} / \mathrm{g}$.

Concerning the species Haplochromis sp captured in our rivers, it also contains a high concentration of mercury as shown in Table II. It appears from our results that the fish of the Kimbi river are those which present the highest concentration in $\mathrm{Hg}$ than the fish of the other rivers studied. With an average of around $7.46 \mu \mathrm{g} / \mathrm{g}$ followed respectively by the Misisi rivers with an average concentration of $3.43 \mu \mathrm{g} / \mathrm{g}$, Makungu $3.29 \mu \mathrm{g} / \mathrm{g}$, Eto' $3.02 \mu \mathrm{g} / \mathrm{g}$, Lubichako 2, $74 \mu \mathrm{g} / \mathrm{g}$, Kacumvi $2.34 \mu \mathrm{g} / \mathrm{g}$, Mandje with a content of $1.69 \mu \mathrm{g} / \mathrm{g}$ and the Kimuti river which has the highest concentration of the series with $1.42 \mu \mathrm{g} / \mathrm{g}$. Similar work in Brazil, Turkey and Argentina has shown that benthic species can accumulate high concentrations of mercury [23], [25], [26].

As for the species Oreochromis sp, observations made on species Silurus sp and Haplochromis sp also seem identical to it. The Kumbi river remains the one with the highest $\mathrm{Hg}$ concentration in fish $(5.95 \mu \mathrm{g} / \mathrm{g})$ followed respectively by the Misisi rivers $2.75 \mu \mathrm{g} / \mathrm{g}$, Makungu $2.62 \mu \mathrm{g} / \mathrm{g}$, Eto' $2.42 \mu \mathrm{g} / \mathrm{g}$, Lubichako $2.19 \mu \mathrm{g} / \mathrm{g}$, Kacumvi $1.88 \mu \mathrm{g} / \mathrm{g}$, Kuwa $1.55 \mu \mathrm{g} / \mathrm{g}$, Mandje $1.36 \mu \mathrm{g} / \mathrm{g}$ and the Kimuti river remains the least polluted of all with a concentration of $1.14 \mu \mathrm{g} / \mathrm{g}$. Although it contains high concentrations of mercury $(\mathrm{Hg})$, this species has lower values than the two previous species, namely Silurus sp and Haplochromis sp. In 2006, Koffi et al showed that fish species from the Ivorian coast also contain mercury [17].

Referring to the quality standards of fishery products, it turns out that all the fish caught in the various rivers of the Fizi gold panning zones have a total concentration of $\mathrm{Hg}$ considerably exceeding the standards according to which recommends that the concentration in total mercury in fish cannot exceed $0.5 \mu \mathrm{g} / \mathrm{g}$. Similar results were found by Nsambu et al. [10] who had studied the mercury contamination of fish from the Fizi gold panning areas [10].

Fish from the Kimbi River have the highest selenium content of all rivers with averages of $8.63 \pm 0.34 \mu \mathrm{g} / \mathrm{g}$, $6.31 \pm 0.53 \mu \mathrm{g} / \mathrm{g}$ and $7.87 \pm 0,43 \mu \mathrm{g} / \mathrm{g}$ respectively for the species Silurus sp, Oreochromis sp and Haplochromis sp. As for the mercury content in the different rivers, the selenium (Se) content follows the same variations, with the Kimuti river which has the lowest selenium content with averages of $1.99 \pm 0.04 \mu \mathrm{g} / \mathrm{g}, \quad 1.56 \pm 0.02 \mu \mathrm{g} / \mathrm{g}$ and $1.83 \pm 0.03 \mu \mathrm{g} / \mathrm{g}$ 
respectively for the species Silurus $s p$, Oreochromis $s p$ and Haplochromis sp. Selenium being an indicator to lower the level of mercury in the body, we note that its content is relatively higher than that of mercury in our samples. It is a good thing to minimize the risk of mercury contamination. Similar results from high concentrations of selenium relative to mercury in fish have been found in tropical estuaries in southeast Brazil [25], in Turkish waters [23], in the Colorado River basin in the southwest of the United States [14].

It has been proven that an excess of Se over $\mathrm{Hg}$ confers a protective effect on fish. Selenium has a high binding affinity for $\mathrm{Hg}$ and $\mathrm{MeHg}$, which leads to the formation of biologically unavailable $\mathrm{Se}-\mathrm{Hg}$ precipitates. Glove et al. [27] suggested that a $\mathrm{Se} / \mathrm{Hg}$ molar ratio greater than 1 largely protects the harmful effects of $\mathrm{Hg}$ and that risk assessments should consider $\mathrm{Se} / \mathrm{Hg}$ ratios rather than tissue concentrations of $\mathrm{Hg}$ alone.

The results relating to the molar ratios of total selenium / total mercury $(\mathrm{SeT} / \mathrm{HgT})$ for the different fish species as a function of the rivers are presented in Table II. We have shown that not all the fish species caught in these different rivers constitute not a threat to human health, i.e. they are very safe for human consumption because their SeT/HgT molar ratios are greater than 1 as recommended by the standard [15], [27], [28]. With a ratio $(\mathrm{SeT} / \mathrm{HgT})$ greater than 1 , the antagonistic effect occurs between mercury and selenium, the latter thus protecting aquatic organisms against the toxicity of mercury. Similar results have been found in previous work [14], [23]-[26].

TABLE III. MASS CONCENTRATION AND MOLAR RATIOS OF MERCURY AND SELENIUM IN CRABS AND MOLLUSCS

\begin{tabular}{|c|c|c|c|c|c|c|c|}
\hline & \multirow[t]{2}{*}{ Sample } & \multicolumn{3}{|c|}{ Crabs } & \multicolumn{3}{|c|}{ MolluscsLimnaea sp } \\
\hline & & $\begin{array}{c}\text { Mercury } \\
\text { content }(\mu \mathrm{g} / \mathrm{g})\end{array}$ & $\begin{array}{l}\text { Selenium content } \\
(\mu \mathrm{g} / \mathrm{g})\end{array}$ & $\begin{array}{c}\text { Molar ratios } \\
\mathrm{Se} / \mathrm{Hg}\end{array}$ & $\begin{array}{c}\text { Mercury } \\
\text { content }(\mu \mathrm{g} / \mathrm{g})\end{array}$ & $\begin{array}{c}\text { Selenium } \\
\text { content }(\mu \mathrm{g} / \mathrm{g})\end{array}$ & $\begin{array}{c}\text { Molar ratios } \\
\mathrm{Se} / \mathrm{Hg}\end{array}$ \\
\hline Eto ${ }^{\prime}$ & 12 & $1.93 \pm 0.27$ & $2.34 \pm 0.27$ & 3.22 & $1.54 \pm 0.12$ & $1.96 \pm 0.12$ & 3.24 \\
\hline Kacumvi & 11 & $1.45 \pm 0.15$ & $1.92 \pm 0.12$ & 3.43 & $1.12 \pm 0.15$ & $1.62 \pm 0.04$ & 3.68 \\
\hline Kimbi & 13 & $4.76 \pm 0.90$ & $5.18 \pm 0.23$ & 2.83 & $3.81 \pm 0.88$ & $4.23 \pm 0.02$ & 2.82 \\
\hline Kimuti & 11 & $0.90 \pm 0.19$ & $1.32 \pm 0.03$ & 4.00 & $0.72 \pm 0.01$ & $1.14 \pm 0.01$ & 4.03 \\
\hline Kuwa & 14 & $1.23 \pm 0.14$ & $1.65 \pm 0.05$ & 3.33 & $0.99 \pm 0.03$ & $1.40 \pm 0.05$ & 3.60 \\
\hline Lubichako & 14 & $1.74 \pm 0.19$ & $2.16 \pm 0.25$ & 3.38 & $1.34 \pm 0.11$ & $1.83 \pm 0.02$ & 3.47 \\
\hline Makungu & 15 & $2.08 \pm 0.28$ & $2.50 \pm 0.28$ & 3.10 & $1.67 \pm 0.18$ & $2.09 \pm 0.01$ & 3.18 \\
\hline Mandje & 12 & $1.07 \pm 0.14$ & $1.49 \pm 0.05$ & 3.61 & $0.88 \pm 0.02$ & $1.30 \pm 0.02$ & 3.76 \\
\hline Misisi & 16 & $2.20 \pm 0.26$ & $2.28 \pm 0.24$ & 2.79 & $1.76 \pm 0.11$ & $2.31 \pm 0.03$ & 3.34 \\
\hline
\end{tabular}

In addition to the three species of fish studied previously, we also measured in parallel the selenium and the mercury in the crabs and molluscs Limnaea $s p$ populating the various rivers because being part of the food habits of the neighboring populations. Regarding its results, we observe that all rivers are all polluted and that the Kimbi river remains the most polluted with an average of $4.76 \pm 0.90 \mu \mathrm{g} / \mathrm{g}$ of $\mathrm{Hg}$ in crabs and $3.81 \pm 0,88 \mu \mathrm{g} / \mathrm{g}$ in molluscs; as for the Kimuti river, it remains the least polluted with averages of 0.90 $\mu \mathrm{g} / \mathrm{g} \pm 0.01 \mu \mathrm{g} / \mathrm{g}$ of crabs and $0.72 \pm 0.01 \mu \mathrm{g} / \mathrm{g}$ of molluscs Limnaea sp. The Se content remains higher compared to that of $\mathrm{Hg}$ in the various samples $(5.18 \pm 0.23 \mu \mathrm{g} / \mathrm{g}$ for the crabs and $4.23 \pm 0.02 \mu \mathrm{g} / \mathrm{g}$ for the molluscs of the Kimbi river). Our previous results had shown that the Kimbi river was the most polluted because it is the confluence of eight other rivers. Consequently, it turns out that all Limnaea $s p$ crabs and molluscs populating the rivers of the Fizi gold panning regions do not pose any risk for human consumption, especially since their $\mathrm{Se} / \mathrm{Hg}$ molar ratios are greater than 1 well. that the total mercury content greatly exceeds the normative limits.

\section{CONCLUSION}

In the present study, crabs, fish species and molluscs are considerably important food sources, commonly consumed by local populations. It has been found that crabs, fish (Silurus sp, Oreochromis $s p$ and Haplochromis sp) and Limnaea $s p$ molluscs caught in different rivers of the Fizi panning areas have concentrations of total mercury considerably exceeding the standard according to which the value acceptable in fish and shellfish should not exceed 0.5 $\mu \mathrm{g} / \mathrm{g}$. In addition to this, Silurus $s p$ fish had the highest total mercury levels compared to other fish followed by Haplochromis $s p$ and Oreochromis $s p$ fish respectively. However, not all of these fish species studied were found to pose a threat to human health because their molar ratios of total selenium and total mercury (TSe: $\mathrm{THg}$ ) are at least greater than 1 . In such circumstances, the antagonistic effect between mercury and selenium occurs, in that selenium protects aquatic organisms from mercury toxicity. In view of the above, it is necessary to combat mercury pollution of aquatic ecosystems in gold mining sites in the territory of in order to preserve both the health of aquatic organisms and the health of consumers of the above-mentioned fishery products. It would be important to train gold miners in the Fizi territory in the proper management of gold mining effluents, the promotion of modern artisanal gold mining techniques that significantly reduce environmental pollution, etc.

\section{ACKNOWLEDGMENT}

We sincerely thank the gold miners, the gold traders and the inhabitants of the gold mining sites in the Fizi territory; Mr Kanku Mukonkole Clément for lending us a strong hand during the correction of this manuscript. 


\section{REFERENCES}

[1] Bereket Abraha, H.A., Abdu Mahmud, Negasi Tsighe, Xia Wen Shui, Yang Fang., Effect of processing methods on nutritional and physicochemical composition of fish: a review. MOJ Food Processing \& Technology., 2018. 6(4): p. 376-382.

[2] Yu Han, H.H., Lihong Yang, Guolian Chen, Yucong Wen, Riming Huang., Nutritional characteristics of marine fish Sardinella zunasi Bleeker and immunostimulatory activities of its glycoprotein. . Royal Society of Chemistry., 2019. 9: p. 30144-30153.

[3] Nkrumah T, A.W.Y., Microbiological and Nutritional Properties of Frankfurter-Type Fish Sausage. International Journal of Nutrition., 2018. 2(4): p. 27-34.

[4] Oksana Vatslavovna Tabakaeva, A.V.T., Wojciech Piekoszewski., Nutritional composition and total collagen content of two commercially important edible bivalve molluscs from the Sea of Japan coast. J Food Sci Technol., 2018. 55(12): p. 4877-4886.

[5] Roslizawati Ab Lah, J.S., Dale Savins, Ashley Dowell, Daniel Bucher, Kirsten Benkendorff., Investigation of nutritional properties of three species of marine turban snails for human consumption. Food Science \& Nutrition., 2017. 5(1): p. 14-30.

[6] Violetta Aru, B.K., Klavs Martin Sørensen, Søren Balling Engelsen., The foodome of bivalve molluscs: From hedonic eating to healthy diet. Journal of Food Composition and Analysis., 2018. 69: p. 13-19.

[7] Chen., T.-T.L.D.-W., Soldier crab (Mictyris brevidactylus), a resource of nutritional food material. Journal of Applied Animal Research., 2020. 48(1): p. 109-113.

[8] Wan Roslina Wan Yusof, F.B.A., Noorasmin Mokhtar Ahmad, Awang Sallehin Awang Husaini \& Mummedy Swamy., Proximate Composition and Antioxidant Properties of Orange Mud Crab, Scylla olivacea. Journal of Aquatic Food Product Technology., 2019. 28(4): p. 365-374.

[9] Anita Kumari, Y.S.D., A Study on Nutritional Composition and Value Addition of Crab Apple (Malus baccata). American Journal of Food Science and Technology., 2017. 5(1): p. 19-22.

[10] Nsambu Mukondwa Pascal, M.E.A.D., Mputu Kanyinda Jean-Noël., Determination of the Level of Mercury Toxicity of Fish in Rivers Draining Gold Panning Sites in the Territory of Fizi, Eastern Democratic Republic of Congo. International Journal of Environmental Protection and Policy., 2020. 8(1): p. 1-10.

[11] Corvi., C., Metals and micropolluants in the water, mussels and fish of lake Geneva., in Campagne, P.C.I.P.e.L.c. pollution, Editor. 2004: France. p. 55-78.

[12] C. Grasmick, S.C., N. Fréry, A. Boudou, R. Maury-Brachet., La pollution mercurielle liée à l'orpaillage en Guyane : contamination des systèmes aquatiques et impact sanitaire chez les Amérindiens du HautMaroni. Revue d'Ethnobiologie., 1998. 40(1-2): p. 167-179.

[13] Igor Živković, M.Š., Jože Kotnik, Suzana Žižek, Milena Horvat., The Bioaccumulation of Mercury, Methylmercury and Other Toxic Elements into Pelagic and Benthic Organisms. Acta Adriatica., 2017. 58(3): p. 391-418

[14] Natalie K. Day, T.S.S., James J. Roberts, Barbara C. Osmundson, James J. Willacker, Collin A. Eagles-Smith., Mercury and selenium concentrations in fishes of the Upper Colorado River Basin southwestern United States: A retrospective assessment. PlosOne, 2020. 13: p. 1-20.

[15] Polak-Juszczak., L., Distribution of organic and inorganic mercury in the tissues and organs of fish from the southern Baltic Sea Environmental Science and Pollution Research., 2018. 25: p. 3418134189.

[16] Kamilou Ouro-Sama, H.D.S., Kissao Gnandi, Komlan Mawuli Afiademanyo et Essô Joseph Bowessidjaou., Évaluation et risques sanitaires de la bioaccumulation de métaux lourds chez des espèces halieutiques du système lagunaire togolais. La revue électronique en science de l'environnement., 2014. 14(2): p. 1-19.

[17] Kouamé M. Koffi, G.H.M.B., Yolande Ake-Assi, N'zi G. Agbo., Estimation de l'apport en mercure à partir de la consommation de poisson en Côte d'Ivoire. Sciences \& Nature., 2007. 4(2): p. 171-177.

[18] O. Simon, A.B., Direct and Trophic Contamination of the Herbivorous Carp Ctenopharyngodon idella by Inorganic Mercury and Methylmercury. Ecotoxicology and Environmental Safety., 2001. 50: p. 48-59.

[19] Mohamad Assad, J.P., David Cazaux, Frédéric Gimbert, Michel Chalot, Fabienne Tatin-Froux., Mercury uptake into poplar leaves. Chemosphere., 2016. 146: p. 1-7.

[20] Nsambu Mukondwa Pascal, M.E.A.D., Mputu Kanyinda Jean-Noël., Contribution to the evaluation of the level of mercury pollution of the soils of gold mining sites in the territory of Fizi, Eastern of Democratic Republic of Congo. Journal of Materials and Environmental Sciences., 2020. 11(1): p. 85-100.
[21] Nsambu Mukondwa Pascal, M.E.A.D., Mputu Kanyinda Jean-Noël., Evaluation of the Level of Mercury Pollution in the Sediments of the Rivers Draining the Gold Panning Sites in the Territory of Fizi, Eastern Democratic Republic of Congo. Journal of Geoscience and Environment Protection., 2020. 8: p. 97-111.

[22] Nsambu Mukondwa Pascal, M.E.A.D., Mputu Kanyinda Jean-Noël. Concentration of Total Mercury in the Blood, Urine and Hair of Gold Panners, Gold Traders, People Living in and Around Gold Panning Sites in the Territory of Fizi, DRC. International Journal of Ecotoxicology and Ecobiology., 2020. 5(1): p. 1-12.

[23] Safak Ulusoy, S.M., F.Saadet Karakulak, Abdullah E. Kahraman. Selenium-Mercury Balance in Commercial Fish Species from the Turkish Waters. Biological Trace Element Research, 2019. 191: p 207-213.

[24] Semona Issa, T.M.C., Øyvind Mikkelsen, Sigurd Einum, Veerle L. B. Jaspers., Biofilms grown in aquatic microcosms affect mercury and selenium accumulation in Daphnia. Ecotoxicology., 2020. 29: p. 485 492.

[25] Alice Bosco Santos, W.L.S., New Evaluation of Selenium: Mercury Ratios in Fish and Crabs from an Impacted Tropical Estuary, Southeastern Brazil. International Journal of Environmental Sciences \& Natural Resources. , 2017. 2(3): p. 1-5.

[26] Marina Arcagni, A.R., Romina Juncos, Majda Pavlin, Linda M. Campbell, María A. Arribrére, Milena Horvat, Sergio Ribeiro Guevara., Mercury and selenium in the food web of Lake Nahue Huapi, Patagonia, Argentina. Chemosphere., 2017. 166: p. 163-173.

[27] H. E. Ganther, C.G., M. L. Sunde, M. J. Kopecky, P. Wagner, SangHwan Oh, W. G. Hoekstra., Selenium: Relation to Decreased Toxicity of Methylmercury Added to Diets Containing Tuna. Science, 1972. 175(4026): p. 1122-1124.

Jean-Noël Mputu Kanyinda is a Doctor of Science from the University of Liège (Belgium) in Chemistry and Biochemistry, coordinator in Biopharma qualification and validation; $\mathrm{PhD}$ student in mining environment at the Faculty of Polytechnic (University of Mons / Belgium). Specialist in food processing and heavy metal contamination, he is a professor at the University of Kinshasa.

Nsambu Mukundwa Pascal holds a Masters in Environment and is a $\mathrm{PhD}$ student in Environmental Sciences at the University of Kinshasa.

Dieudonné Musibono is a doctor in Aquatic Sciences / Ecotoxicology from the University of Cape Town, South Africa. He also holds two postdoctorates in Terrestrial Ecotoxicology (University of Stellenbosch, South Africa) and in Integrated Ecosystem Management / Global Environment at Brown University (Providence, Rhodes Island, USA). Biologist and environmentalist, he is a professor at the University of Kinshasa. 